\title{
PURCHASE OF FRESH FRUITS AND VEGETABLES THROUGH BOX SCHEMES IN HUNGARY - OPPORTUNITIES AND HINDERING FACTORS ON THE WAY TO SUSTAINABILITY
}

\author{
Imola Szabó ${ }^{1 *}$, József Lehota ${ }^{1}$, Róbert Magda
}

\author{
'Szent István University, Gödöllő, Hungary \\ ${ }^{2}$ Institute of Economics, Law and Methodology, Szent István University, Gödöllő, Hungary; North-West University, South Africa
}

\begin{abstract}
This study examines opportunities and hindering factors of box schemes as they have been operating for many years in Hungary, but there are several facts which make it hard for box schemes to become parts of the daily routine in the lives of Hungarian consumers. The first fact is price sensitiveness and willingness to pay price premium for environmentally friendly products, including fresh fruits and vegetables. The second fact is the lack of many products in supplies of box schemes, because fruits and vegetables are seasonal products, but this reason is not always acceptable for customers. The third fact is time wasting, which is a really hindering factor. Finally, interpretation of sustainability is the most important in the eyes of consumers. Our goal is to show how the relation between factors leads to opportunity of growth.
\end{abstract}

Keywords: short food supply chain, box schemes, sustainability, price sensitiveness, price premium

\section{Introduction}

As European Parliamentary Research Service definition says; "local agriculture and short food supply chains have economic, social and cultural benefits for farmers, consumers and rural areas in general". It can be useful for social situation and economy, because the demand is evincible among the EU citizens. According to a survey of Eurobarometer, $55 \%$ of EU respondents "totally agree that the EU should encourage local markets and distribution channels", 54\% "also totally agree that there are benefits to buying products from a local farm", 53\% "totally agree that it would be useful to have labels identifying local products" and 52\% "agree that it easy to identify local products" (Eurobarometer, 2011). In Hungary, one way to improve the competitiveness of foods is to produce local and own-brand food products (Bozsik, 2013).

Short food supply chains are driven by consumers' demand and the main cause of their creation is the change of human approach and lifestyle. Besides, the farmers markets have a long history, several new types of short food supply chains existed and became famous in circles of customers in recent decades (Fertő and Mizik, 2016). In Hungary, there are many alternative short food supply systems, such as local food festivals, pick-your-own, farmers markets or farm-gate sales, besides these, community supported systems, community gardens, buying groups and food box delivery are also available (Balázs, 2012). The smaller volume retail chains - mainly operating in the countryside- reacted by increasing the number of their outlets and by continuously adjusting their product range (Bozsik, 2018). In some cases, authors use other designations for types of short food supply chains, for instance box schemes (Harvey et al., 2004; Galli and Brunori, 2013), which "as part of a Community Supported Farm Initiatives deliver mainly fresh and seasonal products (often also organic) from their farms directly to consumers or to deposits in a town" (Galli and Brunori, 2013). This study deals with box schemes.

In general, a typical consumer of a short food supply chain is a highly educated, middle-aged woman with a higher salary, living close to the market and willing to pay a higher price for higher quality. She is interested in sustainability; therefore, she makes her decisions with this in mind. This type of segment is really similar to LOHAS (Lifestyle of Health and Sustainability) segment, which is $8.7 \%$ of the Hungarian population (Szakály et al., 2015). Rácz (2013) examined the size of LOHAS segment in Hungary for the first time, and it was $8 \%$, including the consumers' segment that was the most committed to sustainable lifestyle, which was $4 \%$ of the Hungarian population. Consumers of the community supported system are younger, between 30 s and 40 s, and they also have a higher environmental awareness and live active social lives (Fertő and Mizik, 2016). In the case of community supported direct sales forms, consumers are concentrated and create a network (Lehota, 2012).

In terms of short food supply chains, scholars emphasize that the most important thing is a short geographic distance, by which sustainability can be reached. This distance is $40 \mathrm{~km}$ in Hungary (Fertő and Mizik, 2016). Examining the summarized distance traveled by customers, it seems that it is longer than $40 \mathrm{~km}$ because all goods that they need are not available from one place; therefore, they have to travel to more producers.

\section{Material and methods}

This study shows the box schemes as a part of the short food supply chain in Hungary. We presented the direct sale of fruits and vegetables and examined Hungarian purchase habits. Then, we typified the chosen box schemes including their operation systems, their fruits and vegetables supplies, and their weaknesses and strengths. Box schemes operate in the mark of sustainability; therefore, we examined the relationships among them. In general, box schemes supply products in higher prices, and we compared these with prices of retailers, including a Hungarian retailer and two multinational hypermarkets. We calculated price premium and compared the results with Hungarians' willingness to pay price premium. After this, we could create a conclusion summarizing the opportunities and hindering factors which became clear. The current study is based on secondary data, including several studies, and collected data about box schemes' operation systems. Our price premium calculation is based on collected price data of box schemes and retailers. 


\section{Results and discussion}

\section{Direct sale of fruits and vegetables in Hungary}

Shares of sales of fruits and vegetables in supply chains are differentiated. In 2005, farmers markets (and farm-gate sales) with $20 \%$ and small selfservice shops also with $20 \%$ were the most important to consumers, special stores followed with $17 \%$, then discount stores (12\%), hypermarkets (11\%), supermarkets (11\%), non-self-service stores $(7 \%)$ and $C+C$ and wholesalers (2\%) (Kiss, 2012). Csíkné Mácsai (2011) conducted research in a group of fruits and vegetables producers, who sell their products to consumers directly. Almost 50\% of producers answered that direct sale for customers is their only form of sale; they did not use any other roles in their supply chain. Csíkné Mácsai and Lehota (2013) examined producers in the case of their sales practices. The results presented that $60 \%$ of examined producers answered that they sell directly to consumers. $25 \%$ of examined producers sold through POs (Producer Organizations) (in Hungary; TÉSZ) and 15\% of examined producers used mixed sales channels. Producers who sold directly to consumers used the following forms of direct sales especially:

$\square$ farmers market;
$\square$ farm-gate sale;
$\square$ producer shop;
$\square$ food delivery system;
$\square$ catering sales;
$\square$ pick-your-own;
$\square$ online sales.

This study examined the main goals that were the most important for producers. In the case of producers who sold directly, these significant aims were:

$\square$ to produce high quality products;

$\square$ to keep current farming management level;

$\square$ to achieve the highest income;

$\square$ to have delight in the work;

$\square$ to contribute to the positive judgment of the profession;

$\square$ to maintain values of the region;

$\square$ to increase the proportion of direct sales;

$\square$ to achieve respect of other producers;

$\square$ and to have more free time besides work.

Szabó and Juhász (2012) examined Hungarian consumers' purchase habits. In terms of the purchase of fruits and vegetables, almost $60 \%$ of participants answered that they bought fruits and vegetables on markets. That is, they chose direct sales, which harmonized with the study of Csíkné Mácsai and Lehota (2013).

Médiaunió Alapítvány (Hungarian foundation) and Ipsos conducted joint research about Hungarians' purchase habits in 2018. According to the representative research, which included 1000 Hungarian participants, published in August in 2018, almost all of the population thought that Hungarian foods are tasty and have a long tradition of good quality and reliable origins; therefore, Hungarian people like to buy Hungarian foods. In the case of purchases, the most important thing for Hungarian customers is price. The second thing is quality, and the third thing is taste. Origin is just the fourth, and health and diet are just sixth. Many other studies also showed that price is always the most significant factor in the buying process (Szakály et al., 2012; Lehota et al., 2014). Approx half of Hungarian consumers have not committed themselves to a healthy diet yet (Szakály et al., 2012). Hungarian customers said that the most important Hungarian foods that they purchase are fruits and vegetables. They are followed by meat and meat products, and milk, milk products and eggs. Despite Hungarian foods having a good reputation in groups of buyers, only $30 \%$ of Hungarians chose Hungarian food consciously (Médiaunió Alapítvány - Ipsos, 2018).

Next, we will show one of the specific forms of alternative food supply types, box schemes, while their operation systems offer more than the delivery of food boxes, which is the basis. They only sell local products directly to consumers, like food box delivery or baskets systems with the aim to build a buyer community. They are more and more popular in the defined consumer segment in Hungary.

There are some box schemes in Hungary that sell mostly controlled quality and some organic products, thus more customers can find the best price online. We compared these box schemes with two multinational hypermarkets' and one Hungarian supermarket's online ordering system to know more about price differences and the different operating systems that they use.

\section{Box schemes and sustainability}

Box schemes link the producers with consumers by products and build a relationship between them and other buyers. Buyers, members and producers of box schemes are committed to sustainability which is also reflected in the fact that many volunteers help their work. One of the first box schemes was Szatyorbolt in Hungary, it started its operations in 2005 as a small buyer community, but it has been operating as association since 2011 (Kajner, Lányi and Takács-Sánta, 2013). In 2014, there were four box schemes in Hungary (Csíkné Mácsai, 2014), in 2017, there were five box schemes and thirteen buyers' communities according to Tudatos Vásárlók Egyesülete. However, after a fast online search it can be seen that the number of those has been constantly increasing and the two categories (box schemes and buyer communities) have been merging.

We examined three Hungarian box schemes and compared them to better understand their operations and goals, and we were interested in prices of their products, especially fruits and vegetables prices to know their price level to compare it with retailers' prices. Two of the box schemes operate in Budapest and the third one operates in the Pest County.

When we chose box schemes, our goal was to avoid organic products because of their higher prices; therefore, most of our examples are not organic. However, when box schemes do not sell other products, for instance onion and sweet pepper in the case of the second box scheme, we showed the organic prices, as seen in a table under the names of vegetables.

There are some difficulties in the case of box schemes. The first one is the difference between operation systems. In some cases, for instance, they have minimum ordering costs or a minimum quantity, or their members have to pay a membership fee. Moreover, one of them delivers twice a week and the others deliver just once a week, or they only have pick-up points, where customers can receive their orders. Delivery costs are really different and they do not cover all Hungary, thus if someone wants to join them, but the box scheme does not deliver there, the customer will need to choose a different box scheme. Because their operation systems differ from each other, if customers want to join more box schemes, they have to pay attention to their specialties. In contrast, these are not problems to retailers' online ordering. Retailers have some benefits, such as having almost every product available to order online and in person, the territory of delivery is bigger than in the case of box schemes, and they have more pick-up points and their delivery is more flexible, including delivery almost every day. Delivery costs can be calculated after creating an account and finalizing the order. 
The second one is the supply of fruits and vegetables in box schemes. As we examined them, it seemed that in many cases they did not have all of the fruits and vegetables or not the desired varieties that consumers wanted to buy. The reason for the lack of fruits and vegetables is the seasonality, but it is not sure that all customers accept this, despite their willingness to pay more for higher and controlled quality. The willingness to pay a higher price for higher quality is one part of the awareness of consumers' thinking, but the time wasted while shopping in multiple places does not encourage people to buy from box schemes. As a consequence, consumers have to spend too much time buying higher controlled quality or organic products, which is harmful for awareness thinking.

The third one is the higher prices. LOHAS and consumers of box schemes are willing to pay more, but comparing their prices with retailers' prices, the differences are significant.

However, purchases from box schemes give many benefits to customers. First of all, traceability is easier, because customers can check producers, whose names are available on webpages of box schemes. This can mean bigger security and trust for consumers and good marketing for producers and for the countryside, where products originate. As Magda and Marselek (2010) wrote, "settlement marketing is a synthesizing, coordinator tool, which positions, communicates and presents itself as a unified image. Settlement marketing steps consist of analysis of markets, development of goals and planning strategies, specification of elements of marketing, especially geographical marketing-mix, implementation and evaluation."

Local food sales through box schemes can mean an opportunity to apply an expansion strategy as part of their strategy. Moreover, it can mean local products and settlement promotion as a tool of marketing communication. As Kerek and Marselek (2009) wrote, roles of local initiatives and local communities are more important to develop the countryside in a changing world. As Nagy, Tóth and Oláh (2012) defined, "the aim is to achieve that the profits and benefits of economic activities (e.g. products, services, jobs or income) could be used locally." According to Fertő and Mizik (2016) short food supply chains can build local communities and develop them. Moreover, "fruits and vegetables sector needs marketing" - as Ledó, Ferenc CEO of
Fruitveb, said (Czékus, 2015). In this case, marketing does not just mean sales promotion or exchange of economic goods, but as Magda (2003) wrote, it means exchange of psychological (emotional) and social (included status) values.

\section{Prices and supplies}

We compared prices of box schemes with prices of online ordering in the case of two multinational companies and a Hungarian retailer. The first problem was finding the same products in every order, because in some cases, there was a lack of exactly defined species of products, or they did not sell some products in this term, or they sold just organic types. As a result, three fruits and three vegetables were compared considering their prices. The products involved in the investigation are two types of apples, namely "Gala" and "Golden", one type of pear, it was "Vilmos", potatoes (separated by production year and method), onion and sweet pepper. More fruits and vegetables added would have resulted in an increased lack of data; consequently, it seems that box schemes are not able to service all products at the same time, because if they are seasonal, their producers do not always produce the same types and species. This does not mean that their practice is not good, just that customers need to buy from more box schemes, and if they want to purchase from them, they must travel more than if they buy everything in a big store or online from retailers. If we think about it in a broad sense, more travel to buy from box schemes affects the outcome of sustainability which can topple over in a negative scale.

The question is: is purchasing higher quality and controlled products more important for customers than saving time and buying everything in the same place? Moreover, the really important question is, whether sustainability means just economic and environmental cases or thinking over the human attitude, which one considers at the first place. More precisely defined, human attitude is what people do for themselves and what they do with others, including the environment, food wasting and thus money wasting leading to economic issues including financial awareness or non-awareness. As Magda elaborates (2013), that sustainability "involves maximising the net benefits of economic development, subject to maintaining the services and the quality of

Table 1 Comparison of fruits and vegetables prices in the case of box schemes and retailers

\begin{tabular}{|c|c|c|c|c|c|c|}
\hline \multirow[t]{2}{*}{ Name of product } & \multicolumn{3}{|c|}{ Box schemes } & \multicolumn{3}{|c|}{ Retailers } \\
\hline & 1. & 2. & 3. & 1. & 2. & 3. \\
\hline Apple (Gala) & $\begin{array}{l}580 \text { HUF } \\
1.77 €\end{array}$ & $\begin{array}{l}350 \text { HUF } \\
1.07 €\end{array}$ & $\begin{array}{l}350 \text { HUF } \\
1.07 €\end{array}$ & $\begin{array}{c}399 \text { HUF } \\
1.22 €\end{array}$ & $\begin{array}{c}269 \text { HUF } \\
0.82 €\end{array}$ & $\begin{array}{c}349 \text { HUF } \\
1.06 €\end{array}$ \\
\hline Apple (Golden) & $\begin{array}{c}480 \text { HUF } \\
1.46 €\end{array}$ & - & $\begin{array}{c}250 \text { HUF } \\
0.76 €\end{array}$ & $\begin{array}{c}369 \text { HUF } \\
1.13 €\end{array}$ & $\begin{array}{c}369 \text { HUF } \\
1.13 €\end{array}$ & $\begin{array}{c}349 \text { HUF } \\
1.06 €\end{array}$ \\
\hline Pear (Vilmos) & $\begin{array}{l}590 \text { HUF } \\
1.80 €\end{array}$ & - & - & $\begin{array}{l}799 \text { HUF } \\
2.44 €\end{array}$ & $\begin{array}{c}649 \text { HUF } \\
1.98 €\end{array}$ & $\begin{array}{c}599 \text { HUF } \\
1.83 €\end{array}$ \\
\hline Potatoes & $\begin{array}{l}435 \text { HUF } \\
1.33 €\end{array}$ & - & $\begin{array}{l}160 \text { HUF } \\
0.49 €\end{array}$ & $\begin{array}{l}229 \text { HUF } \\
0.70 €\end{array}$ & $\begin{array}{l}240 \text { HUF } \\
0.73 €\end{array}$ & $\begin{array}{c}149 \text { HUF } \\
0.45 €\end{array}$ \\
\hline - new & $\begin{array}{l}234 \mathrm{HUF} \\
0.71 €\end{array}$ & - & - & $\begin{array}{c}199 \text { HUF } \\
0.61 €\end{array}$ & $\begin{array}{l}139 \text { HUF } \\
0.42 €\end{array}$ & $\begin{array}{c}199 \text { HUF } \\
0.61 €\end{array}$ \\
\hline - organic & - & $\begin{array}{c}590 \text { HUF } \\
1.80 €\end{array}$ & $\begin{array}{l}470 \text { HUF } \\
1.43 €\end{array}$ & $\begin{array}{c}399 \text { HUF } \\
1.22 €\end{array}$ & - & - \\
\hline Onion & $\begin{array}{l}415 \text { HUF } \\
1.27 €\end{array}$ & $\begin{array}{c}690 \text { HUF } \\
2.10 € \text { (organic) }\end{array}$ & $\begin{array}{l}180 \text { HUF } \\
0.55 €\end{array}$ & $\begin{array}{c}\text { 219HUF } \\
0.67 €\end{array}$ & $\begin{array}{c}219 \text { HUF } \\
0.67 €\end{array}$ & $\begin{array}{l}199 \mathrm{HUF} \\
0.61 €\end{array}$ \\
\hline Sweet pepper & $\begin{array}{c}630 \text { HUF } \\
1.92 €\end{array}$ & $\begin{array}{c}830 \text { HUF } \\
2.53 € \text { (organic) }\end{array}$ & $\begin{array}{l}400 \text { HUF } \\
1.22 €\end{array}$ & $\begin{array}{c}\text { 499 HUF } \\
1.52 €\end{array}$ & $\begin{array}{l}549 \text { HUF } \\
1.67 €\end{array}$ & $\begin{array}{c}499 \text { HUF } \\
1.52 €\end{array}$ \\
\hline
\end{tabular}

Source: Date of prices comparison: between $4^{\text {th }}$ and $5^{\text {th }}$ of September, 2018. Data collected from online web stores 
natural resources over time... Active participation in sustainable development ensures that those who are affected by the changes are the ones determining the changes." According to Dudás (2011), there are groups of customers, one of them involving consumers with environmental awareness and the other involving consumers who have health awareness. As Dudás said, financial awareness is placed between the two groups, but it must be developed in Hungary.

The results of the compared prices of the examined box schemes and retailers in the case of online orders are shown in Table 1. Prices are in Hungarian currency and Euros, calculated in the average exchange rate between September 4 and 5 in 2018 when 1 euro was equal to 328 HUF (http://www.mnbkozeparfolyam.hu/arfolyam-2018-09.html).

It can be seen that the first box scheme operates with higher prices than the second one. As the second box scheme sells just organic in many cases of their products, prices of onion and sweet pepper are higher. During the examined period, apples (variety of Golden), pears (variety of Vilmos), and potatoes, excluding organic, were not available on the webpage. The third box scheme offers almost all products that we examined, excluding pears (variety of Vilmos) and new potatoes. Its products have lower prices because of its location, out of Budapest.

Comparing online orders of retailers, it can be seen that almost all of the examined products are available in their supplies. In the cases of apples (variety of Golden), new potatoes, onion and sweet pepper, their prices fall in similar categories, especially in the supplies of two multinational companies. The prices of the Hungarian retailer present more differences; sometimes they are higher or lower than in the second multinational company. In this examination, prices of the first multinational company are the highest, but customers cannot be sure about the quality of products. Thus higher prices can mean higher quality or just simply higher profit for the company. However, comparing prices of multinational companies, prices are the same in several cases. The reason is the market competition between them.

Analyzing the two buying options, it seems that prices scale on a wide range. In many cases, the online orders of retailers' prices are lower, but customer do not get enough information about products and their quality and producers, because this exact information is not available on sites. The question is; is known quality or price more important for customer? Customers who are interested in purchasing from box schemes are willing to pay higher prices for getting controlled or organic products or products that are produced in the mark of sustainability. It is not easy to calculate the amount of extra money, because demands and supplies change by location, products, seasons and year by year. Lehota (2018) examined Hungarian consumers' willingness to pay premium price for foods. The results showed that they are willing to pay $0-10 \%$ more on average. Consumers who are willing to pay more than $10 \%$ are more interested in better taste, quality and security of foods, but environmentally friendly and ethical foods were the least important.

Following Duram (2011), who calculated the price premium of prices of organic products compared with prices of conventional products, we used the modified formula for box schemes and retailers to present a price premium comparing those.

$$
\begin{aligned}
& \text { Price premium }=[(\text { price of box schemes }- \\
& \text { price of retailers }) / \text { price of retailers }] \times 100
\end{aligned}
$$

We counted price premium in the case of apples (Gala), potatoes, onion and sweet pepper. Firstly, we calculated the average prices of box schemes and retailers separately. In the case of apples, we counted with the three prices of box schemes and the three prices of retailers, but in the case of potatoes, onion and sweet pepper, we used only the first and the third box schemes prices and the first and third retailers' prices to get average prices. We did not calculate with the prices of organic products, because those belong to a higher price category. The calculated price premiums are:

$\begin{array}{ll}\square \text { Apple (Gala): } & 26 \% . \\ \square \text { Potatoes: } & 57 \% . \\ \square \text { Onion: } & 42 \% . \\ \square \text { Sweet pepper: } & 3.2 \% .\end{array}$

It can be seen that box schemes offer products with a significantly higher prices compared to retailers' prices. Comparing the results with research of Lehota Zs. it seems, that the price premiums are much higher than the Hungarian consumers' willingness to pay price premium. It can be stated that the higher prices of box schemes are a hindering factors besides a lot of opportunities, such as Hungarian taste, quality, food security and the young people' commitment to sustainability.

\section{Conclusion}

We analyzed box schemes operation systems with their weaknesses and potentials compared to their competitors. We showed Hungarian consumers' prices sensitiveness, including willingness to pay price premium for ethical or environmentally friendly foods, and we got the result that Hungarian customers are willing to pay more money just for better taste, quality and security. Any other issues, including ethical or environmental, are less important. However, Hungarian customers really like the domestic taste of foods, especially fruits and vegetables; therefore, they choose Hungarian fruits and vegetables almost every time, if they can do it. This is a right way in direction to commitment, which is worth taking into consideration for box schemes. Hungarian taste, Hungarian fruits and vegetables and security would be good keywords for box schemes to encourage consumers to choose healthy lives, healthy foods and healthy thinking. The main segment which can be reached easier is young or younger people, who wish to belong to a group and build a community for sustainability; it is a motivational power that can spread over generations.

\section{References}

BALÁZS, B. 2012. Local food system development in Hungary. In International Journal of Sociology of Agriculture and Food, vol. 19, 2012, no. 3, pp. 403-421. http://www. ijsaf.org/archive/19/3/balazs.pdf (Accessed: 23 Sept 2018)

BOZSIK, N. 2018. Some Characteristics of the Hungarian Agri-food Industry After Joining the European Union In Zéman, Z. - Magda, R. (ed.) Controller Info Studies II. Budapest, Magyarország : Copy \& Consulting Kft., 2018, pp. 60-69.

BOZSIK, N. 2013. The Competitiveness of Hungarian Agri-Food Products on the Market of the European Union. In Contemporary Research on Organization Management and Administration, vol. 1, 2013, pp. 39-48.

CSÍKNÉ MÁCSAI, É. 2014. Közvetlen értékesítés a mezőgazdasági termékek piacán. Doktori (PhD) értekezés. Gödöllő, 2014.

CSÍKNÉ MÁCSAI, É. 2011. Közvetlen értékesítés a zöldség-gyümölcs termelők körében. In Gazdálkodás, vol. 55, 2011, no. 5, pp. 494-501.

CSÍKNÉ MÁCSAI, É. - LEHOTA, J. 2013. Mezőgazdasági termelők értékesítési csatornaválasztási döntéseinek vizsgálata, különös tekintettel a közvetlen értékesítésre. In Gazdálkodás, vol. 57, 2013, no. 5, pp. 451-459.

CZÉKUS, M. 2015. Marketingre vár a magyar zöldség-gyümölcs ágazat. http://agraragazat. hu/cikk/marketingre-var-magyar-zoldseg-gyumolcs-agazat (Accessed: 23 Sept 2018).

DUDÁS, K. 2011. A tudatos fogyasztói magatartás dimenziói. In Vezetéstudomány, vol. 42, 2011, no. 7-8, pp. 47-55.

DURAM, L.A. (ed.). 2011. Encyclopedia of organic, sustainable, and local food. Lincoln : University of Nebraska Press, 2011. 
EUROBAROMETER. 2011. The Common Agricultural Policy. Report. http://ec.europa.eu/ commfrontoffice/publicopinion/archives/ebs/ebs 368 en.pdf (Accessed: 15 Sept 2018)

EUROPEAN PARLIAMENTARY RESEARCH SERVICE. 2013. Local Agriculture and Short Food Supply Chains. https://epthinktank.eu/2013/10/14/local-agriculture-and-shortfood-supply-chains/ (Accessed: 15 Sept 2018)

FERTŐ, I. - MIZIK, T. (eds.). 2016. Agrárgazdaságtan I. Budapest : Akadémia Kiadó, 2016, pp. 306-326.

GALLI, F. - BRUNORI, G. (eds.). 2013. Short Food Supply Chains as drivers of sustainable development. Evidence Document. Document developed in the framework of the FP7 project F00DLINKS (GA No. 265287). Laboratorio di studi rurali Sismondi, 2013, pp. 1-6.

HARVEY, M. - McMEEKIN, A. - WARDE, A. (eds.). 2004. Qualities of food. Manchester and New York : Manchester University Press, 2004, pp. 14, 133 p.

KAJNER, P. - LÁNYI, A. - TAKÁCS-SÁNTA, A. (eds.). 2013. A fenntarthatóság felé való átmenet jó példái Magyarországon. 2013, pp. 169-173.

KEREK, Z. - MARSELEK, S. 2009. A vidékfejlesztés gyakorlata, lehetőségek, intézkedések. Budapest : Szaktudás Kiadó Ház, 2009, 33 p.

LEHOTA, J. 2012. Értékesítési sajátosságok - közvetlen értékesítési csatornák In Szakály, Z. - Szente, V. Agrártermékek közvetlen értékesítése, marketingje, Magyar Agrárkamara Business sorozat, 117-154. p. In Csíkné Mácsai, É. 2014. Közvetlen értékesítés a mezőgazdasági termékek piacán. Doktori (PhD) értekezés. Gödöllő. https://szie.hu/file/tti/archivum/Csikne Macsai Eva ertekezes.pdf (Accessed: 20 Sept 2018)

LEHOTA, J. - HORVÁTH, Á. - RÁCZ, G. 2014. The effect of sustainability on the information search behaviour of Hungarian consumers through the practice of food purchasing. In Acta Alimentaria, vol. 43, 2014, no. 3, pp. 437-443. https://akademiai.com/doi/ pdf/10.1556/AAlim.43.2014.3.10 (Accessed: 22 Sept 2018)

LEHOTA, Zs. 2018. A hazai élelmiszerellátási lánc elemzése, különös tekintettel a fogyasztói kockázatokra. Doktori (PhD) értekezés. Gödöllő. https://szie.hu/sites/default/files/ lehota zsuzsanna ertekezes.pdf (Accessed: 23 Sept 2018)

MAGDA, R. 2013. Difficulties in sustainability and land utilisation. In Visegrad Journal on Bioeconomy and Sustainable Development, vol. 2, 2013, no. 1, p. 15-18. https://vua. uniag.sk/sites/default/files/Magda 15-18.pdf (Accessed: 22 Sept 2018)

MAGDA, R. - MARSELEK, S. (eds.). 2010. Vidékgazdaságtan I. A vidékfejlesztés gazdasági folyamatai. Budapest : Szaktudás Kiadó Ház, 2010, pp. 262-264.

MAGDA, S. (eds.). 2003. A mezőgazdasági vállalkozás szervezése és ökonómiája I. A mezőgazdasági vállalkozások gazdálkodásának alapjai. Budapest: Szaktudás Kiadó Ház, 2003, 157 p.
MAGYAR NEMZETI BANK. Középárfolyam figyelő. http://www.mnbkozeparfolyam.hu/ arfolyam-2018-09.html (Accessed: 5 Sept 2018)

MÉDIAUNOÓ - IPSOS. 2018. A hazai minden előtt? Így vásárol a magyar. http://www. mediaunio.hu/a-hazai-minden-elott-2018

NAGY, H. - TÓTH, T. - OLÁH I. 2012. The role of local market in the sustainable economic development of Hungarian rural areas. In Visegrad Journal on Bioeconomy and Sustainable Development, vol. 1, 2012, no. 1, pp. 27-31. https://vua.uniag.sk/sites/ default/files/27-31.pdf (Accessed: 22 Sept 2018)

RÁCZ, G. 2013. Az értékek változásának és a fenntartható fejlődés trendjének hatása a hazai élelmiszerfogyasztásra. Doktori (PhD) értekezés. Gödöllő. https://szie.hu/file/ tti/archivum/Racz Georgina ertekezes.pdf (Accessed: 14 0ct 2018)

SZABÓ, D. - JUHÁSZ, A. 2012. A piacok szerepe és lehetőségei a hazai élelmiszer-ellátási láncban. In Gazdálkodás, vol. 56, 2012, no. 3, pp. 217-229.

SZAKÁLY, Z. - PETŐ, K. - POPP, J. - JASÁK, H. 2015. A LOHAS szegmens mérete és jellemzői Magyarországon. In Táplálkozásmarketing, vol. II, 2015, no. 1, pp. 11-30. http://taplalkozasmarketing.com/wp-content/uploads/02 Szak\%C3\%A1ly-Z.Pet\%C5\%91-K.-Jas\%C3\%A1k-H. A-LOHAS-szegmens-m\%C3\%A9rete-\%C3\%A9sjellemz\%C5\%91i-Magyarorsz\%C3\%A1gon final.pdf (Accessed: 22 Sept 2018)

SZAKÁLY, Z. - SZENTE, V. - KÖVÉR, G. - POLERECZKI, Z. - SZIGETI, 0. 2012. The influence of lifestyle on health behavior and preference for functional foods. In Appetite, vol. 58, 2012, no. 1, pp. 406-413. http://apps.webofknowledge.com/full record.

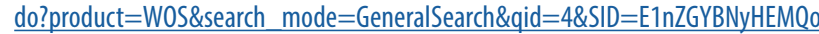
$\underline{\mathrm{xUg} 60 \text { \&page }=1 \& d o c=4 \& \text { cacheur|FromRightClick=no }}$ (Accessed: 25 June 2018)

TUDATOS VÁSÁRLÓK EGYESÜLETE. 2017. Működő közösségi gazdaságok, dobozrendszerek és bevásárlóközösségek. https://tudatosvasarlo.hu/cikk/mukodo-kozossegimezogazdasagi-csoportok-bevasarlokozossegek (Accessed: 10 Jan 2019)

Z. KISS, L. (eds.). 2012. Versenyképes zöldségtermelés. Budapest : Mezőgazda Kiadó, 2012, $258 \mathrm{p}$.

\section{Contact address}

Imola Szabó, PhD student, Doctoral School of Management and Business Administration, Szent István University, Faculty of Economics and Social Sciences, H-2100 Gödöllő, Páter Károly street 1, e-mail: 1.szabo.imola@gmail.com 